\title{
The effect of skipping combination with body weight training on cardiorespiratory endurance and body mass index (BMI) as a Covid-19 prevention effort for overweight adolescents
}

\author{
Ahmad Nasrulloh $^{1 *}$, Rina Yuniana ${ }^{1}$, Kukuh Wahyudin Pratama ${ }^{2}$ \\ ${ }^{1}$ Sports Science Department, Faculty of Sports Science, Yogyakarta State University, Jl. Colombo No. \\ 1, Karangmalang, Depok, Sleman, Special Region of Yogyakarta, Indonesia. \\ ${ }^{2}$ Center for Sport and Exercise Sciences, University Malaya, Jalan Universiti, 50603 Kuala Lumpur, \\ Malaysia \\ *Corresponding Author. E-mail: ahmadnasrulloh@uny.ac.id
}

Received:June 23, 2021; Accepted:August 23, 2021; Published: September 25, 2021

\begin{abstract}
This study aims to determine the effect of skipping combination with body weight training on cardiorespiratory endurance and BMI as an effort to prevent Covid-19 for overweight adolescents. This research is an experimental research. In this study, treatment was given in the form of skipping exercise combined with body weight training for 8 weeks with a frequency of 3 times/ week, an intensity of $60 \%$ $70 \%$ MHR with a duration of 30 minutes. The population in this study were teenagers. Sampling was done by purposive sampling on adolescents aged between 17-21 years and overweight. Instrument used to measure $\mathrm{VO}_{2}$ max with MFT (multistage fitness test) and measurement of height and weight to determine BMI. The data analysis technique used prerequisite test and paired t test. Based on the results of the cardiorespiratory endurance data analysis, the t-count value was 10.495 with a significance value of 0.000 , it can be concluded that there is a significant effect of skipping combination with body weight training on cardiorespiratory endurance in overweight adolescents. The mean value of the cardiorespiratory endurance pretest was 34.92 and the posttest average increased to 40.05 . While the results of the analysis on BMI data obtained a t-count value of 15.293 with a significance value of 0.000 , it can be concluded that there is a significant effect of skipping combination with body weight training on BMI in overweight adolescents. The mean value of the BMI pretest was 26.60 and the posttest average BMI decreased to 22.19 . So it can be concluded that skipping exercises combined with body weight training can increase cardiorespiratory endurance and reduce BMI as an effort to prevent Covid-19 for overweight adolescents.
\end{abstract}

Keywords: skipping, body weight training, cardiorespiratory endurance, BMI, overweight, Covid-19

How to Cite: Nasrulloh, A., Yuniana, R., \& Pratama, K. W. (2021). The effect of skipping combination with body weight training on cardiorespiratory endurance and body mass index (BMI) as a covid-19 prevention effort for overweight adolescents. Jurnal Keolahragaan, 9(2), 220-230. doi: https://doi.org/10.21831/jk.v9i2.41678

\section{INTRODUCTION}

Corona virus disease (Covid-19) which is a respiratory tract infection caused by severe acute respiratory syndrome coronavirus 2 (SARS-CoV-2). It is well known that Covid-19 is a very serious world health problem. This Covid-19 case stems from information from the World Health Organization (WHO) on December 31, 2019. Cases of Covid-19 quickly spread throughout the world, so that in March 2020, Wolld Health Organization declared Covid-19 a global pandemic. The first case in Indonesia was announced by the President of the Republic of Indonesia on March 2, 2020, there have been 2 confirmed cases of Covid-19. Since then, the Indonesian government has begun to take preventive measures to prevent wider spread of Covid-19. Until April 1, 2021, Indonesia has reported through BNPB that number of confirmed cases of Covid-19 in Indonesia has reached $1,517,854$ positive cases of Covid-19 with the number of patients who recovered as many as $1,355,578$ people and as many as 41,054 people died active positive Covid-19 reached 121,222 people 
(bnpb.go.id, 2021). Meanwhile, in the Special Region of Yogyakarta as of April 1, 2021, 33,648 people were confirmed positive, with 27,786 patients having recovered and 814 having died, so that up to now there are still 5048 active positive cases (corona.jogjaprov.go.id, 2021). The data shows that the transmission of Covid-19 is still showing a significant increase. Therefore, it is necessary to take anticipatory steps to completely break the spread of Covid-19, so that there are no more additional positive cases.

Covid-19 can be transmitted from human to human through coughing/sneezing droplets. Prevention of the spread of Covid-19 can be done at the community level and at the individual level. At the community level, physical or social distancing needs to be carried out by keep in distance between people, working from home, avoiding crowds, using masks when leaving the house and reducing traveling by public transportation. Prevention from the individual level by maintaining personal hygiene. This can be done by washing your hands more often with soap and water for at least 20 seconds or using an alcohol-based hand sanitizer, avoiding touching your eyes, nose and mouth with unwashed hands, not shaking hands, avoiding, (Kemenkes Republik Indonesia, 2020).

Currently, the central government is working hand in hand with local governments to tackle the Covid-19 disaster by vaccinating as a primary prevention effort for all Indonesians. As of April 1, 2021, 40,349,051 people have been vaccinated where the vaccination is divided into three main priorities, 1,468,764 given to Health Human Resources, 17,327,169 to public officers and 21,553,118 given to the elderly (bnpb.go.id, 2021). The data shows that the elderly, public officers and medical personnel are the main priority to be given vaccinations so that their immunity against the Covid-19 virus can increase. From the distribution of vaccination data, it has not been seen that the adolescent age group has not yet received priority for vaccination.

Adolescence is a period of transition or transition, which is a period in which individuals physically and psychologically change from childhood to adulthood, (Jannah, 2017). According to WHO, the age limit for adolescents is between 12 and 24 years. The age range of adolescence is the age of 12 to 14 years is called pre-adolescence, the age of 14 to 17 years is referred to as early adolescence and the age of 17 to 21 years is an advanced teenager, (Diananda, 2019).

During this Covid pandemic, most teenagers rarely want to do physical activity. Most teenagers tend to prefer spend their time playing gadgets which leads to overweight. Overweight is a global problem that cannot be ignored. In developing countries, the largest number of overweight men is found in Asia. There are 60\% of the population or about 10.6 million people. Overweight can be influenced by several factors, one of which is environmental factors, including problems in choosing the type of food, eating patterns, servings per meal and the level of activity in each individual, (Husain et al., 2015). Lack of physical activity causes teenagers to be overweight. Situations like this can certainly be detrimental to the health and fitness of teenagers. Therefore, it is necessary to have special treatment for teenagers in order to be able to improve physical fitness and maintain weight so that overweight does not occur.

One example that overweight teenagers can do to increase their immunity and physical fitness is by doing exercise/physical activity. Physical exercise can be done by each individual to improve fitness/cardiorespiratory endurance and it can also lose weight. On the other hand, exercise to increase cardiorespiratory endurance is very important nowaday considering the Covid-19 virus that attacks the respiratory tract, so cardiorespiratory resistance is very much needed to prevent transmission. There are several main things that can be done to increase self-immunity, physical activity, namely by consuming balanced nutrition vitamin supplements, adequate rest, not smoking and controlling comorbidities such as asthma, heart disease, diabetes mellitus, hypertension and cancer.

Durability cardiorespiratory refers to the ability of the lungs, heart, and blood vessels to deliver sufficient amounts of oxygen to the cells to meet the demands of prolonged physical activity, (Antoni et al., 2021; Hoeger \& Hoeger, 2013). As a preventive effort, it is necessary to have a physical activity that can help increase the ability of cardiorespiratory endurance because cardiorespiratory strenght is currently very important to deal with the spread of Covid-19. One of the physical activities that can be done is aerobic exercise. Aerobic exercise is a systematic exercise activity with a gradual and continuous increase in load that uses energy derived from combustion using oxygen, and requires oxygen without causing fatigue, (Palar et al., 2015). Some examples of aerobic exercise are running, aerobic gymnastics swimming, cycling, skipping, and jogging. 
Currently, all Indonesian citizens are encouraged to practice social distance, so it is necessary to choose physical activities that prioritize these recommendations. Physical activity that can be done independently and done at home is aerobic exercise that can be combined with body weight training. The situation of the covid pandemic in Indonesia and especially Yogyakarta, which has experienced an increase, needs to choose exercises that are safe and easy to do at home without the need for large areas of land. One of the easiest aerobic exercises to do at home is skipping. Skipping is an activity that uses a rope with both ends of the rope being held with both hands and then swinging it from head to toe while jumping over it, (Setyawan, 2020).

In addition to aerobic exercise in the form of skipping, physical exercise can be done by combining it with body weight exercises so that boredom does not occur when doing physical activities. Body weight training is a type of weight training that can be done without using tools, and using your own body as a weight, (Muhammad et al., 2016). Body weight training is a form of weight training by focusing on loading using the weight of the body itself. Exercises using deep weights tend to be easier to do anywhere because the loading system only uses one's own body weight, (Nasrulloh et al., 2018). Body weight training can be done using weights from your own body weight such as chin-ups, jumping jacks, planks, push-ups, squat trusts, squat jumps, sit-ups, lunges, back-ups and so on. In addition, body weight training can also be done with total-body resistance exercise (TRX), (Nasrulloh \& Wicaksono, 2020).

\section{METHOD}

This research is an experimental research. The research design in this study was the one-group pretest-posttest design. In this study, treatment was carried out in the form of skipping exercises combined with body weight training to increase cardiorespiratory endurance and reduce Body Mass Index (BMI). The population in this study were adolescents. Sampling was done by purposive sampling. The criteria are adolescents, aged 17 to 21 years, overweight and willing to be the research sample.

Instruments which is used to measure cardiorespiratory endurance ( $\left.\mathrm{VO}_{2} \max \right)$ with Multistage Fitness Test. The norms for the multistage fitness test are as follows:

\begin{tabular}{|c|c|c|c|c|c|c|}
\hline Age & Very Poor & Poor & Fair & Good & Excellent & Superior \\
\hline $13-19$ & $<25.0$ & $25.0-30.9$ & $31.0-34.9$ & $35.0-38.9$ & $39.0-41.9$ & $>41.9$ \\
\hline $20-29$ & $<23.6$ & $23.6-28.9$ & $29.0-32.9$ & $33.0-36.9$ & $37.0-41.0$ & $>41.0$ \\
\hline $30-39$ & $<22.8$ & $22.8-26.9$ & $27.0-31.4$ & $31.5-35.6$ & $35.7-40.0$ & $>40.0$ \\
\hline $40-49$ & $<21.0$ & $21.0-24.4$ & $24.5-28.9$ & $29.0-32.8$ & $32.9-36.9$ & $>36.9$ \\
\hline $50-59$ & $<20.2$ & $20.2-22.7$ & $22.8-26.9$ & $27.0-31.4$ & $31.5-35.7$ & $>35.7$ \\
\hline $60+$ & $<17.5$ & $17.5-20.1$ & $20.2-24.4$ & $24.5-30.2$ & $30.3-31.4$ & $>31.4$ \\
\hline
\end{tabular}

Figure 1. Norms of multistage fitness test (MFT)

The instrument used to determine BMI (body mass index) is to measure height using a stadiometer and measure body weight using a weight scale. After measuring height and weight, to be able to find out the body mass index can be entered in the formula:

$\mathrm{BMI}$ formula $=\frac{\text { berat badan }(\mathrm{kg})}{\text { tinggi badan }(\mathrm{m})^{2}}$

Table 1. Body mass index (BMI) norm

\begin{tabular}{cc}
\multicolumn{2}{c}{ Table 1. Body mass index $($ BMI) norm } \\
\hline BMI & Classification \\
\hline$<18.5$ & Thin \\
$18.5-21.99$ & Normal \\
$22.0-24.99$ & Normal \\
$25.0-29.99$ & Overweight \\
$30.0-34.99$ & Obesity I \\
\hline
\end{tabular}




\begin{tabular}{cc}
\hline $35.0-39.99$ & Obesity II \\
40.00 & Obesity III \\
\hline
\end{tabular}

(Hoeger \& Hoeger, 2013).

\section{Result}

\section{RESULTS AND DISCUSSION}

This study aims to determine the effect of combination skipping exercise with body weight training on cardiorespiratory endurance and BMI as an effort to prevent Covid-19 for overweight adolescents. The treatment was carried out for eight weeks with a frequency of three times a week. Research data collection was carried out 2 times, namely before and after treatment including data on cardiorespiratory endurance which was known to use $\mathrm{VO}_{2}$ max data and BMI data.

The data obtained from the results of the research were then carried out descriptive analysis to determine the description of the data and facilitate the presentation of research data are as follows.

\section{Description of Cardiorespiratory Endurance Data}

Table 2. Results of Descriptive Analysis of Cardiorespiratory Endurance Data

\begin{tabular}{ccccccc}
\hline Data & Min. & Max. & mean & median & Mode & Std. Dev \\
\hline Pretest & 26,20 & 41.90 & 34.92 & 34.55 & 33.90 & 3.43 \\
Posttest & 34.90 & 46.50 & 40.05 & 40,50 & 40,50 & 3.08 \\
\hline
\end{tabular}

Source: Data processed 2021

The results of the cardiorespiratory endurance data analysis at the time of the pretest obtained the lowest score was 26.20 and the highest score was 41.90 . The results of descriptive statistical analysis obtained mean $(M)=34.92$; Median $(\mathrm{Me})=34.55$; Mode $(\mathrm{Mo})=33.90$ and Standard Deviation $(\mathrm{SB})=3.43$. While the results of the cardiorespiratory endurance data analysis at the time of the posttest obtained the lowest score was 34.90 and the highest score was 46.50. The results of descriptive statistical analysis obtained mean $(\mathrm{M})=40.05$; Median $(\mathrm{Me})=$ 40.50; Mode $(\mathrm{Mo})=40.50$ and Standard Deviation $(\mathrm{SB})=3.08$. Based on the results of the analysis, the mean value of the cardiorespiratory endurance pretest was 34.92 and the posttest data of cardiorespiratory endurance after receiving treatment increased to 40.05 .

\section{Cardirespiratory Endurance}

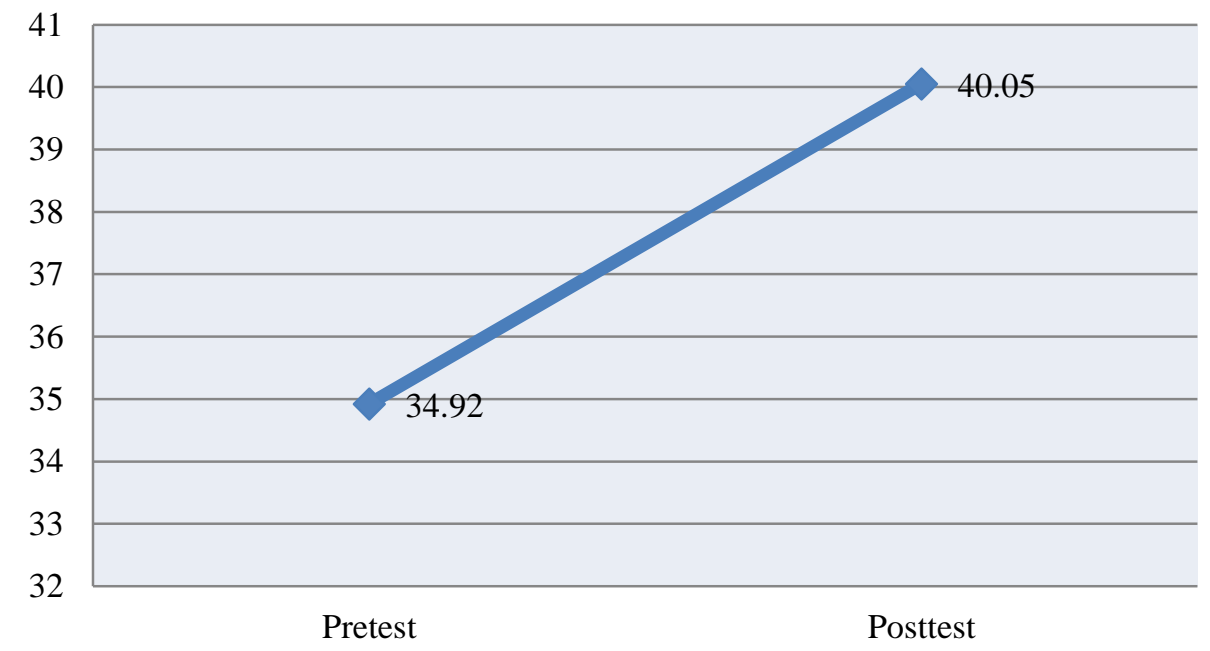

Figure 2. Graph of Cardiorespiratory Endurance Data During Pretest and Posttest

The cardiorespiratory endurance data was then categorised to determine the trend of data classification using existing norms. The results of the cardiorespiratory endurance data categorization at the pretest and posttest are as follows. 
Jurnal Keolahragaan 9 (2), 2021 - 224

Ahmad Nasrulloh, Rina Yuniana, Kukuh Wahyudin Pratama

Table 3. Cardiorespiratory Endurance Data Category

\begin{tabular}{|c|c|c|c|c|}
\hline \multirow[t]{2}{*}{ Category } & \multicolumn{2}{|c|}{ Pretest } & \multicolumn{2}{|c|}{ Posttest } \\
\hline & Frequency & $\%$ & Frequency & $\%$ \\
\hline Superior & 0 & 0.0 & 2 & 10.0 \\
\hline Excellent & 2 & 10.0 & 13 & 65.0 \\
\hline good & 6 & 30.0 & 4 & 20.0 \\
\hline Fair & 10 & 50.0 & 1 & 5.0 \\
\hline Poor & 2 & 10.0 & 0 & 0.0 \\
\hline Very Poor & 0 & 0.0 & 0 & 0.0 \\
\hline Total & 20 & 100.0 & 20 & 100.0 \\
\hline
\end{tabular}

The results of the categorization of cardiorespiratory endurance data at the time of the pretest were found to be 2 people (10\%) in the excellent category, 6 people $(30 \%)$ in the good category, and as many as 10 people (50\%) in the fair category. Furthermore, there are 2 people $(10 \%)$ in the poor category. It can be concluded that the cardiorespiratory endurance data at the time of the pretest were mostly fair.

The posttest data categorization is known as 2 people (10\%) in the superior category, as many as 13 people (65\%) in the excellent category and as many as 4 people (20\%) in the good category. As many as 1 person (5\%) in the fair category. Nothing is categorized as poor or very poor. It can be concluded that cardiorespiratory endurance at the time of the posttest was mostly in the excellent category.

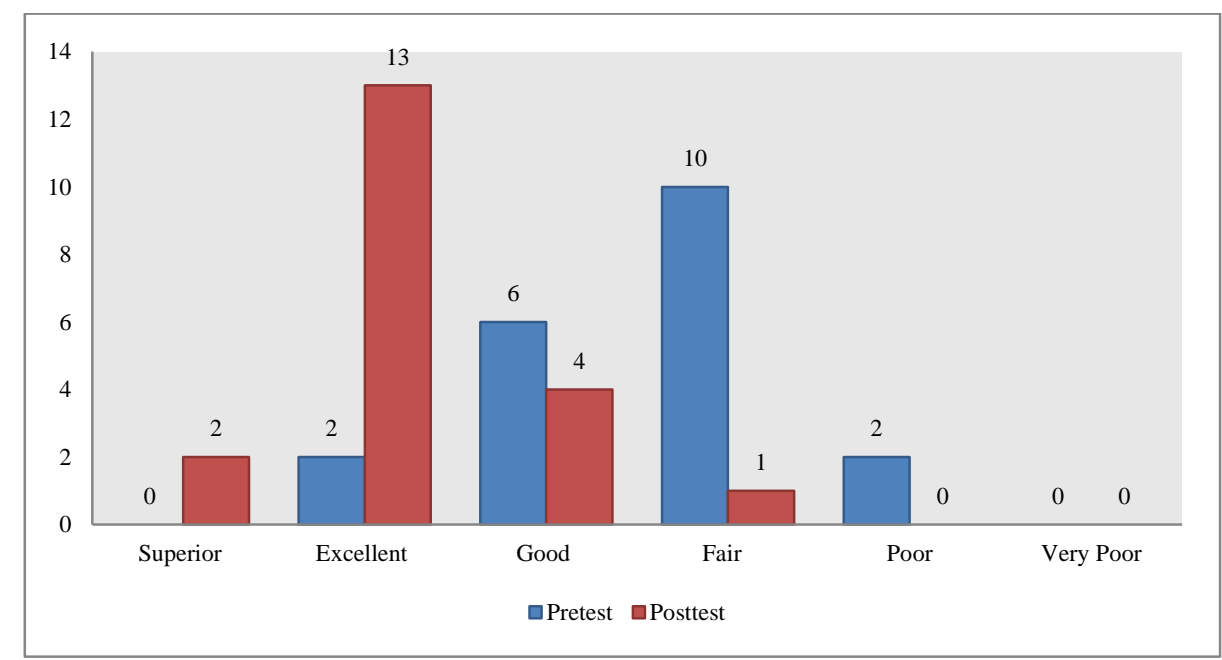

Figure 3. Categorization of Cardiorespiratory Endurance Data

\section{Description of BMI Data}

Table 4. Results of Descriptive Analysis of BMI Data Data

\begin{tabular}{llllccc}
\hline \multicolumn{1}{c}{ Data } & Min. & Max. & mean & median & Mode & Std. Dev \\
\hline Pretest & 25,20 & 29.10 & 26.60 & 26.55 & 25,90 & 1.09 \\
Posttest & 20,20 & 26.60 & 22.19 & 21.65 & 22.60 & 1.72 \\
\hline
\end{tabular}

Source: Data processed 2021

The results of BMI data analysis at the time of pretest obtained the lowest score was 25.20 and the highest score was 29.10. The results of descriptive statistical analysis obtained mean (M) $=26.60$; Median $(\mathrm{Me})=26.55$; Mode $(\mathrm{Mo})=25.90$ and Standard Deviation $(\mathrm{SB})=1.09$. While the results of BMI data analysis at the time of the posttest obtained the lowest score was 20.20 and the highest score was 26.60. The results of descriptive statistical analysis obtained mean (M) $=22.19$; Median $(\mathrm{Me})=21.65$; Mode $(\mathrm{Mo})=22.60$ and Standard Deviation $(\mathrm{SB})=1.72$. Based on the results of the analysis, the average BMI value was 26.60 and the posttest BMI data after receiving treatment decreased to 22.19 . 
IMT

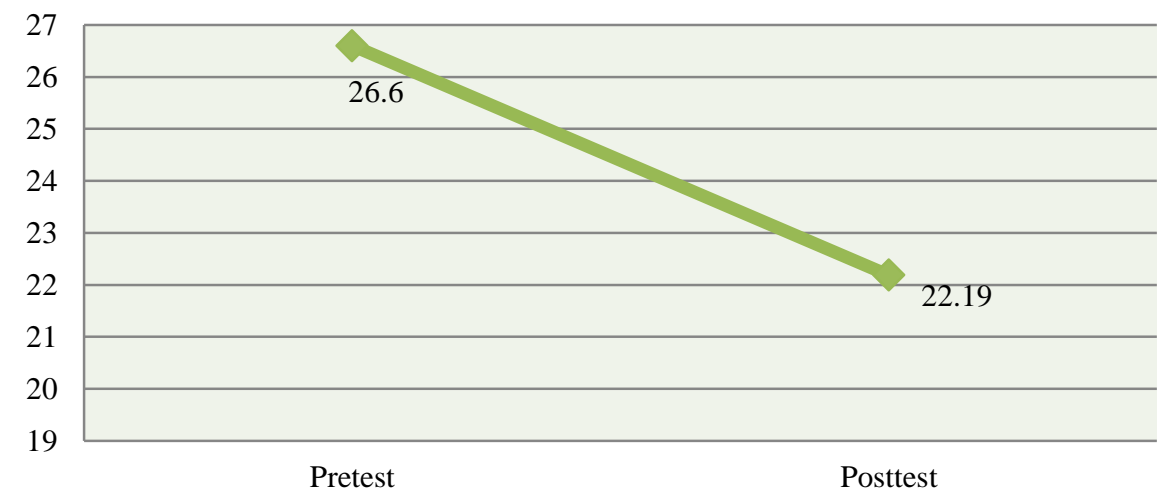

Figure 4. Graph of BMI Data During Pretest and Posttest

The BMI data is then categorised to determine the tendency of data classification using existing norms. The results of BMI data categorization at the pretest and posttest are as follows.

Table 5. Categories of BMI Data

\begin{tabular}{|c|c|c|c|c|}
\hline \multirow[t]{2}{*}{ Category } & \multicolumn{2}{|c|}{ Pretest } & \multicolumn{2}{|c|}{ Posttest } \\
\hline & Frequency & $\%$ & Frequency & $\%$ \\
\hline Thin & 0 & 0.0 & 0 & 0.0 \\
\hline Normal & 0 & 0.0 & 12 & 60.0 \\
\hline Normal & 0 & 0.0 & 6 & 30.0 \\
\hline Overweight & 20 & 100.0 & 2 & 10.0 \\
\hline Obesity I & 0 & 0.0 & 0 & 0.0 \\
\hline Obesity II & 0 & 0.0 & 0 & 0.0 \\
\hline Obesity III & 0 & 0.0 & 0 & 0.0 \\
\hline Total & 20 & 100.0 & 20 & 100.0 \\
\hline
\end{tabular}

The results of the categorization of BMI data at the time of the pretest revealed that all respondents were 20 people $(100 \%)$ in the overweight category. The respondents of this study were selected as overweight teenagers who were overweight so that at the pretest all respondents had a BMI in the overweight category.

BMI at the time of posttest was known as many as 12 people (60\%) in the normal category, 6 people $(30 \%)$ in the normal category and as many as 2 people $(10 \%)$ in the overweight category. It can be concluded that the BMI at the time of the posttest was mostly normal.

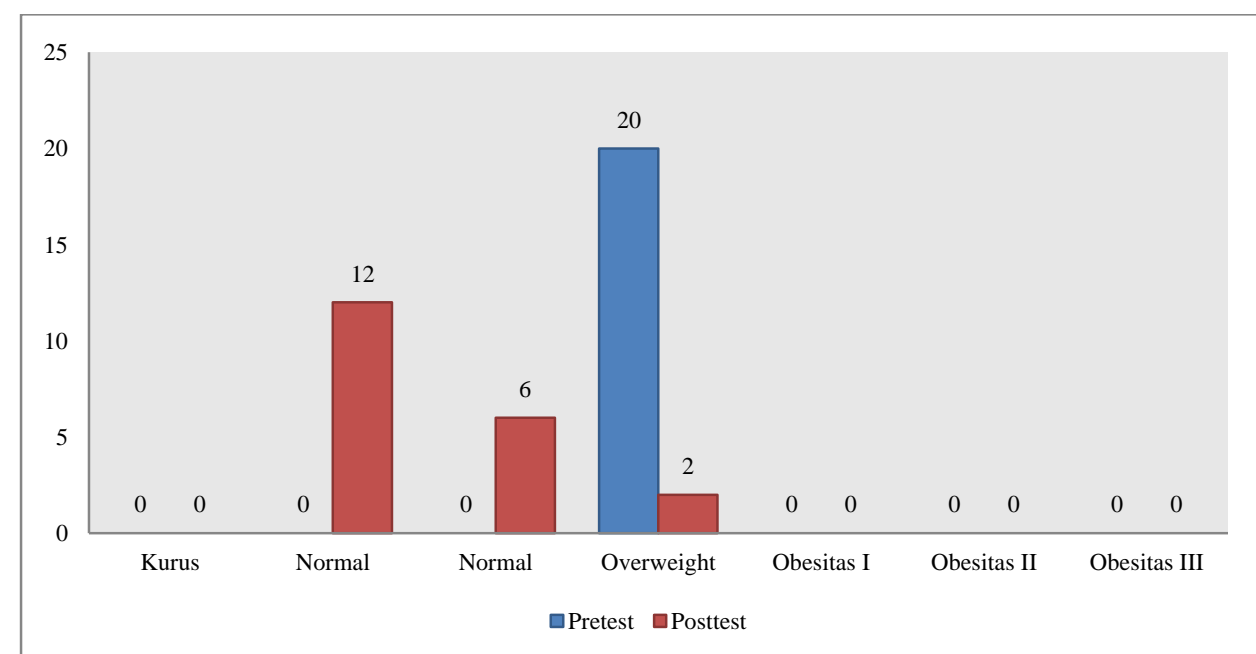

Figure 5. Categorization of BMI Data 


\section{Data Analysis Results}

Before testing the hypothesis, the data needs to be tested for data analysis prerequisites including normality test and homogeneity test.

a. Normality Calculation

Calculation of data normality was carried out using the Kolmogorof Smirnov test. The results of the normality test of the research data are as follows.

Table 6. Normality Test Results of Cardiorespiratory Endurance and BMI

\begin{tabular}{lccc}
\hline \multicolumn{1}{c}{ Data } & KSZ & $\boldsymbol{p}$ & Note. \\
\hline Cardiorespiratory Endurance Pretest & 0.705 & 0.702 & Normal \\
Cardiorespiratory Endurance Posttest & 0.981 & 0.291 & Normal \\
BMI pretest & 0.621 & 0.836 & Normal \\
Posttest BMI & 0.926 & 0.358 & Normal \\
\hline
\end{tabular}

Source: Data processed 2021

The table above shows that the results of the normality calculation of the cardiorespiratory endurance pretest data obtained a significance value of 0.702 and the posttest data obtained a significance value of 0.291 . Because the significance value is greater than 0.05 ( $>0.05$ ), it can be stated that the research data is normally distributed. This means that the distribution of cardiorespiratory endurance data meets the criteria for the data normality curve as a requirement for parametric statistical analysis. While the results of the normality calculation of the BMI pretest data obtained a significance value of 0.836 and the posttest data obtained a significance value of 0.358 . Because the significance value is greater than 0.05 ( $>>0.05)$, it can be stated that the BMI data is normally distributed.

b. Homogeneity Calculation

The statistical test used to test the homogeneity is using the Levene's Test with the F test. The results of the homogeneity test are as follows.

Table 7. Results of Homogeneity of Cardiorespiratory Endurance Data and BMI

\begin{tabular}{lccl}
\hline \multicolumn{1}{c}{ Data } & F count & $\boldsymbol{p}$ & Note. \\
\hline Pretest-Posttest Cardiorespiratory Endurance & 0.078 & 0.782 & Homogeneous \\
Pretest-Posttest BMI & 1,771 & 0.191 & Homogeneous \\
\hline
\end{tabular}

Source: Data processed 2021

The results of the homogeneity test to test the homogeneity of the cardiorespiratory endurance pretest and posttest data obtained a calculated $F$ value of 0.078 with a significance value of 0.782 . By the data significance value greater than 0.05 ( $p>0.05)$, it can be stated that the cardiorespiratory endurance data is homogeneous, so the data is eligible for parametric statistical analysis. Meanwhile, the results of the homogeneity test to test the homogeneity of the BMI pretest and posttest data obtained a calculated $\mathrm{F}$ value of 1.771 with a significance value of 0.191 . By the data significance value is greater than 0.05 ( $p>0.05)$, it can be stated that the BMI data is homogeneous, so the data is eligible for parametric statistical analysis.

\section{Hypothesis test}

Testing the hypothesis of this study using the paired sample $t$ test. Hypothesis 1 of this study is "There is a significant effect of combination skipping exercise with body weight training on cardiorespiratory endurance as an effort to prevent Covid-19 for overweight adolescents". While the second hypothesis of this study is "There is a significant effect of combination skipping exercise with body weight training on BMI as an effort to prevent Covid-19 for overweight adolescents". The results of the paired sample t test on cardiorespiratory endurance and BMI are as follows: 
Jurnal Keolahragaan 9 (2), 2021 - 227

Ahmad Nasrulloh, Rina Yuniana, Kukuh Wahyudin Pratama

Table 8. Results of the t-test of Cardiorespiratory Endurance and BMI Data

\begin{tabular}{llllll}
\hline \multicolumn{1}{c}{ Data } & Observation & mean & t count & $\boldsymbol{p}$ & Note. \\
\hline \multirow{2}{*}{ Cardiorespiratory Endurance } & Pretest & 34.92 & \multirow{2}{*}{10,495} & \multirow{2}{*}{0.000} & \multirow{2}{*}{ Significant } \\
& Posttest & 40.05 & & & \\
\hline BMI & Pretest & 26.60 & 15,293 & 0.000 & Significant \\
& Posttest & 22.19 & & & \\
\hline
\end{tabular}

Source: Data processed 2021

Based on the results of the paired sample $t$ test analysis on cardiorespiratory endurance data, the t-count value is 10.495 with a significance value of 0.000 . It can be concluded that there is a significant effect of combination skipping exercise with body weight training on cardiorespiratory endurance as an effort to prevent Covid-19 for overweight adolescents, so the hypothesis 1 is acceptable. While the results of the analysis of the paired sample $t$ test on BMI data obtained a t-count value of 15.293 with a significance value of 0.000 . It can be concluded that there is a significant effect of combination skipping exercise with body weight training on BMI as an effort to prevent Covid-19 for overweight adolescents, so the hypothesis 2 is acceptable.

\section{Discussion}

One of the efforts to prevent the Covid-19 virus from spreading is to increase the body's immunity for every human individual. Immune is very important for a person's body because it will function as an immune system that will protect humans from all kinds of germs, parasites and viruses. Covid-19 is a very dangerous virus, therefore it is necessary to maintain and improve the immune system of the human body, both children, adolescents, adults and the elderly. There are certain factors that affect immune status, including physiological, nutritional, psychological, environmental, and exercise habits or physical activities, (Nurmasitoh, 2015). Exercise and physical activity with moderate intensity on a regular basis will improve the immune system, (Nurmasitoh, 2015). Individuals should be active and do regular physical exercise to boost the immune system and should have adequate sleep, (Chowdhury et al., 2020). Acute exercise (moderate to vigorous intensity, less than 60 minutes) is now seen as an important immune system adjuvant to stimulate the continuous exchange of different and highly active immune cell subtypes between circulation and tissues, with almost daily exercise, these acute changes act through the effects addition to enhance immune defense activity and metabolic health, (Nieman \& Wentz, 2019). Some of the articles above mention that physical activity/exercise can make a positive contribution to the immune system in the body of each individual human being, so it can be said that physical activity has a very important role to be able to increase a person's immune system, both children, adolescents, adults and the elderly.

Physical activity/exercise, in addition to increasing the immune system of the human body, can also improve cardiorespiratory fitness/endurance. Of course, in doing exercise, you must meet the dose of exercise in accordance with the right exercise program so that the goals can be achieved properly. Bompa \& Buzzichelli, (2019) argues that to develop a weight training program, it should meet several components, namely volume, intensity or training load, number of exercises, number of repetitions, exercise rhythm, number of sets, and rest time between sets. The exercise program applied in this study is to combine aerobic exercise as the main exercise in the form of skipping exercise, which is then combined with complementary exercises in the form of body weight training. The dose of exercise given is in the form of skipping exercise which is carried out for 8 weeks with a frequency of 3 times/ week, with an intensity of $60 \%$ - 70\% MHR for 30 minutes. While complementary exercises in the form of body weight training are carried out for 8 weeks with a frequency of 3 times/ week, the number of repetitions is 20 times as much as 3 sets, and with 8 kinds of body weight training movements including; jumping jacks, planks, push-ups, mountain climbs, squat jumps, sit-ups, lunges, and back-ups.

Based on the results of the analysis of this study, it can be seen that the cardiorespiratory endurance data obtained a t-count value of 10.495 with a significance value of 0.000 , it can be concluded that there is a significant effect of combination skipping exercise with body weight training 
on cardiorespiratory endurance. The mean value of cardiorespiratory endurance pretest is 34.92 and posttest data of cardiorespiratory endurance after receiving treatment has increased to 40.05. This proves that the combination skipping exercise program with body weight training can significantly increase cardiorespiratory endurance. When viewed from the results of the categorization, it is known that 2 people (10\%) are in the superior category, 13 people $(65 \%)$ are in the excellent category and 4 people $(20 \%)$ are in the good category. As many as 1 person $(5 \%)$ in the fair category. None were categorized as poor or very poor, so it can be concluded that the cardiorespiratory endurance at the posttest was mostly in the excellent category, namely $65 \%$. The results of this study are in line with the results of the analysis in an article which states that the results of the simple paired t-test test show that there is a difference between the pre-test and post-test data with $p$ value $=0.000$ and $t=5.362$, so it can be concluded that there is an effect of exercise. skipping on increasing cardiorespiratory endurance in school age children 10-12 years, (Rahmawati et al., 2017). Moreira et al., (2008) found in the results of research studied in relation to the training carried out, it can be concluded that an exercise program that includes high and low intensity activities is more efficient to ensure a greater reduction in the risk of heart attack, meaning that this exercise can provide strengthening of heart muscle endurance. Choudhary et al., (2015) also found in their research by showing that regular practice of aerobic exercise for three months improves cardiovascular functions by decreasing sympathetic activity or by increasing vagal tone in medical students. Some of the research results above can support the results of this study which shows that the skipping exercise program combined with body weight training exercises can significantly increase the cardiorespiratory endurance data significantly, with an average value of 40.05 and as much as $65 \%$ included in the excellent category.

The results of the analysis on BMI data obtained a t-count value of 15.293 with a significance value of 0.000 , it can be concluded that there is a significant effect of combination skipping exercise with body weight training on BMI as an effort to prevent Covid-19 for overweight adolescents. As for the analysis, the average BMI value was 26.60 and the posttest BMI data after receiving treatment decreased to 22.19. This proves that the combination skipping exercise program with body weight training can significantly reduce BMI. If you look at the results of BMI categorization at the time of the posttest, it is known that 12 people $(60 \%)$ are in the normal category, 6 people $(30 \%)$ are in the normal category and as many as 2 people $(10 \%)$ are in the overweight category, so it can be concluded that the BMI at the time of the posttest was mostly normal, namely $60 \%$. The results of this study are in line with an article that found that an aerobic training program caused a significant decrease in weight (by $4.3 \mathrm{~kg}, \mathrm{P}=0.003$ ), body mass index (by $1.3 \mathrm{~kg} / \mathrm{m} 2, \mathrm{P}=0.003$ ), free fat mass (by $2.1 \mathrm{~kg}, \mathrm{P}$ $=0.002$ ), total body water (by $0.4 \mathrm{~kg}, \mathrm{P}=0.036$ ), percentage of fat (by 3 percent points, $\mathrm{P}=0.002$ ), (Kostrzewa-nowak et al., 2015). Gullu et al., (2013) found that after 10 weeks of aerobic exercise, there was a decrease in body weight in the running-walking group by $3.58 \%$, BMI by $4.40 \%$, total cholesterol by $6.44 \%$, LDL-K by $7.93 \%$, and triglycerides by $17.75 \%$. In addition, there is a study that found that there was a significant effect of body weight training using a resistance band and without a resistance band on weight loss and fat percentage with a significant value ( $p<0.05$ ), (Lestari \& Nasrulloh, 2019). Some of the results of the research above can strengthen the results of this study which shows that the skipping exercise program combined with body weight training exercises can significantly reduce BMI, with the average decrease being 22.19 and if you look at the category as much as $60 \%$ is included in the normal category.

\section{CONCLUSION}

The exercise program given to overweight adolescents in the form of skipping combined with body weight training exercises can significantly increase the cardiorespiratory endurance data with a significance value of 0.000 , with an average value of 40.05 and most of them in the excellent category as much as $65 \%$. Meanwhile, BMI experienced a significant decrease with a significance value of 0.000 , with an average decrease of 22.19 and $60 \%$ of the categories included in the normal category. Of course, with the increased ability of cardirespiratory endurance and a decrease in BMI, it will also be balanced with an increase in immunity in overweight adolescents. So it can be concluded that skipping exercise combined with body weight training can increase cardirespiratory endurance and reduce BMI as an effort to prevent Covid-19 for overweight adolescents. 


\section{REFERENCES}

Antoni, M. S., Guntur, G., Festiawan, R., Nugraha, A. I., \& Nurhadi, F. I. (2021). Rockport walking fitness test apps: application of cardiorespiration fitness test with rockport method android based. MEDIKORA, 20(1). https://doi.org/10.21831/medikora.v20i1.34960

Bompa, T. O., \& Buzzichelli, C. A. (2019). Peridization: Theory and Methodology of Training. In Journal of Chemical Information and Modeling (Vol. 53, Issue 9).

Choudhary, S., Kumar, J., Choudhary, K., \& Davis, S. (2015). Effect of Aerobic Exercise on Respiratory Parameters In Untrained And Trained Subjects. International Journal of Scientific Research and Management, 3(2), 2090-2096.

Chowdhury, M. A., Hossain, N., Kashem, M. A., Shahid, M. A., \& Alam, A. (2020). Immune response in COVID-19: A review. Journal of Infection and Public Health, 13(11), 1619-1629. https://doi.org/10.1016/j.jiph.2020.07.001

Diananda, A. (2019). Psikologi Remaja Dan Permasalahannya. Journal ISTIGHNA, 1(1), 116-133. https://doi.org/10.33853/istighna.v1i1.20

Gullu, E., Gullu, A., Cicek, G., Yamaner, F., Imamoglu, O., \& Gumusdag, H. (2013). The effects of aerobic exercises on cardiovascular risk factors of sedentary women. International Journal of Academic Research, 5(3), 160-167. https://doi.org/10.7813/2075-4124.2013/5-3/a.23

Hoeger, W., \& Hoeger, S. (2013). Principles and Labs for Physical Fitness.

Husain, A., Tendean, L., \& Queljoe, E. De. (2015). Pengaruh Kelebihan Berat Badan / Overweight Terhadap Terjadinya Disfungsi Seksual Pria. Jurnal E-Biomedik, 3(3). https://doi.org/10.35790/ebm.3.3.2015.10143

Jannah, M. (2017). Remaja Dan Tugas-Tugas Perkembangannya Dalam Islam. Psikoislamedia : Jurnal Psikologi, 1(1), 243-256. https://doi.org/10.22373/psikoislamedia.v1i1.1493

Kemenkes Republik Indonesia. (2020). Panduan Cuci Tangan Pakai Sabun. Kesehatan Lingkungan, 20.

Kostrzewa-nowak, D., Nowak, R., Jastrzębski, Z., Zarębska, A., Bichowska, M., Radzimiński, Ł., Leońska-duniec, A., Ficek, K., \& Cięszczyk, P. (2015). Original papers women. Biochemia Medica, 25(1), 103-113.

Lestari, A., \& Nasrulloh, A. (2019). Efektivitas Latihan Body Weight Training Dengan Dan Tanpa Menggunakan Resistance Band Terhadap Penurunan Berat Badan Dan Persentase Lemak. Medikora, 17(2), 91-101. https://doi.org/10.21831/medikora.v17i2.29180

Moreira, M. M., Souza, H. P. C. de, Schwingel, P. A., Sá, C. K. C. de, \& Zoppi, C. C. (2008). Effects of aerobic and anaerobic exercise on cardiac risk variables in overweight adults. Arquivos Brasileiros de Cardiologia, 91(4), 200-206, 219-226. https://doi.org/10.1590/S0066782X2008001600003

Muhammad, R., Nasrullah, A., Kesehatan, P., \& Uny, F. I. K. (2016). Pengaruh Weight Training Dan Body Weight Training. Urnal of Physical Education and Sports, VX(1), 97-107.

Nasrulloh, A., Prasetyo, Y., \& Apriyanto, K. D. (n.d.). DASAR-DASAR LATIHAN BEBAN.

Nasrulloh, A., \& Wicaksono, I. S. (2020). Latihan bodyweight dengan total-body resistance exercise (TRX) dapat meningkatkan kekuatan otot. Jurnal Keolahragaan, 8(1). https://doi.org/10.21831/jk.v8i1.31208

Nieman, D. C., \& Wentz, L. M. (2019). The compelling link between physical activity and the body's defense system. Journal of Sport and Health Science, 8(3), 201-217. https://doi.org/10.1016/j.jshs.2018.09.009

Nurmasitoh, T. (2015). Physical activities, exercises, and their effects to the immune system. Jurnal Kedokteran Dan Kesehatan Indonesia, 7(2), 52-58. https://doi.org/10.20885/jkki.vol7.iss2.art4 
Jurnal Keolahragaan 9 (2), 2021 - 230

Ahmad Nasrulloh, Rina Yuniana, Kukuh Wahyudin Pratama

Palar, C. M., Wongkar, D., \& Ticoalu, S. H. R. (2015). Manfaat Latihan Olahraga Aerobik Terhadap Kebugaran Fisik Manusia. Jurnal E-Biomedik, 3(1). https://doi.org/10.35790/ebm.3.1.2015.7127

Rahmawati, S., Budiyati, B., \& Indriyawati, N. (2017). Pengaruh Latihan Skipping Terhadap Peningkatan Cardiovascular Endurance Pada Anak Usia Sekolah 10-12 Tahun Di Sdn Plumbon 02 Kecamatan Suruh Kabupaten Semarang. Jurnal Riset Kesehatan, 5(2), 112. https://doi.org/10.31983/jrk.v5i2.2730

Setyawan, Y. (2020). Volume 7 Nomor 1, Maret 2020. 7, 150-164. 